\title{
PERENCANAAN MADRASAH IBTIDAIYAH (MI) SWASTA DI PEDESAAN DALAM MENYELENGGARAKAN PROGRAM TAHFIZ AL-QUR'AN
}

\author{
Ahmad Gawdy Prananosa ${ }^{1}$, Donni Pestalozi ${ }^{2}$, M. Rusni Eka Putra ${ }^{3}$ \\ STKIP PGRI Lubuklinggau ${ }^{1,2,3}$ \\ ahmadgawdyprananosa2020@gmail.com ${ }^{1}$
}

\begin{abstract}
ABSTRAK
Tujuan penelitian ini adalah untuk mengetahui perencanaan madrasah ibtidaiyah (MI) Swasta di pedesaan dalam menyelenggarakan program tahfiz al-qur`an. Penelitian ini menggunakan pendekatan kualitatif dengan metode fenomenologi. Penelitian ini dilaksanakan di Madrasah Ibtidaiyah Assidiq Giriyoso Kecamatan Jayaloka Kabupaten Musi Rawas. Subyek penelitian terdiri dari Kepala Sekolah, Dewan Guru, Pihak Yayasan. Teknik pengumpulan data meliputi; observasi, wawancara dan dokumentasi, teknik analisis data menggunakan interactive model dari Miles dan Huberman, dimana proses analisis dilakukan bersamaan dengan proses observasi dan wawancara serta dokumentasi langsung dilakukan analisis. Hasil penelitian, sangatlah penting merencanakan seluruh komponen sekolah dalam mensukseskan program unggulan madarasah, mulai dari perencanaan kesiswaan, kurikulum, pendididik dan tenaga pendidikan, keuangan, serta hubungan masyarakat, dalam kegiatan perencanaan dapat melibatkan masyarakat sebagai elemen penting untuk mendukung kemajuan madrasah. Kemudian peran wakil rakyat dapat dijadikan relasi atau hubungan baik dalam memajukan Madrasah. Simpulan, Madrasah ibtidiayah Giriyoso telah menyiapkan sarana pendukung seperti pondok tahfiz yang berada di depan kelas, tenaga pendidik dan kependidikan yang fasih dan hafal alqur`an, kurikulum yang tercantum dalam rencana pelaksanaan pembelajaran, kemudian menjalin hubungan baik dengan masyarakat terutama dalam mendukung program sekolah
\end{abstract}

Kata Kunci: Perencanaan, Program Tahfiz Qur`an, Madrasah Ibtidaiyah

\section{ABSTRACT}

The purpose of this study was to determine the planning of private madrasah ibtidaiyah (MI) in rural areas in organizing the tahfiz al-qur'an program. This study uses a qualitative approach with phenomenological methods. This research was conducted in Madrasah Ibtidaiyah Assidiq Giriyoso, Jayaloka District, Musi Rawas Regency. The research subjects consisted of the Principal, the Board of Teachers, the Foundation. Data collection techniques include; observation, interviews and documentation, data analysis techniques using the interactive model of Miles and Huberman, where the analysis process is carried out simultaneously with the observation and interview processes and direct documentation is analyzed. The results of the study, it is very important to plan all components of the school in the success of the madrasa superior program, starting from student planning, curriculum, educators and education personnel, finance, and public relations, in planning activities can involve the community as 
an important element to support the progress of madrasas. Then the role of people's representatives can be used as a relationship or good relationship in advancing Madrasas. In conclusion, Madrasah Ibtidiayah Giriyoso has prepared supporting facilities such as the tahfiz cottage in front of the class, educators and education staff who are fluent and memorized the Koran, the curriculum listed in the learning implementation plan, then establish good relations with the community, especially in supporting school programs.

Keywords: Planning, Tahfiz Qur'an Program, Madrasah Ibtidaiyah

\section{PENDAHULUAN}

Penyelenggaraan madrasah sesuai dengan standar nasional pendidikan yang dirumuskan oleh Pemerintah. Standarisasi yang dimaksud menurut Peraturan Pemerintah Nomor 19 tahun 2005 meliputi standar pendidik tenaga kependidikan, standar proses, standar isi, standar pembiayaan, standar sarana prasarana, standar pengelolaan, standar kompetensi lulusan, dan standar penilaian. Proses standarisasi penyelenggaraan pendidikan, diharapkan agar madrasah mampu bersaing dengan sekolah umum khususnya dalam penyelenggaraan pendidikan umum. Apalagi dalam proses pengelolaan pendidikan, pemerintah telah mendorong adanya otonomi pendidikan. Dengan demikian madrasah bisa lebih leluasa dalam melakukan proses manajemen sekolah yang mengarah pada peningkatan mutu madrasah.

Mewujudkan pendidikan madrasah yang unggul sudah menjadi keharusan, agar dapat bersaing secara kompetitif dan dapat menghasilkan mutu lulusan yang terbaik.Hasil penelitian Madarik (2016) menyatakan madrasah sebagai lembaga pendidikan Islam yang telah mengalami banyak dinamika dalam perjalanan sejarah, eksistensinya sangat dibutuhkan masyarakat muslim. Tetapi tatkala madrasah tidak dikelola secara profesional dengan manajemen yang sistematis, tentu akan menghadapi problematika berat di tengah persaingan yang kompetitif. Oleh karena itu, kelola lembaga pendidikan Islam itu yang berbasis manajemen merupakan yang sudah tidak di tawar lagi. Nyatanya, prinsip-prinsip pendidikan dalam Islam secara normatif sama sekali tidak bertabrakan konsep manajemen

Mewujudkan madrasah yang unggul tidak dapat terlepas dari perencanaan yang unggul juga. Hasil penelitian Sabirin (2012) menyatakan bahwasanya inti dari perencanaan adalah bagaimana proses pelaksanaannya. Karena rencana apapun yang dibuat kalau tidak dilaksanakan maka semua rencana tersebut tidak mempunyai arti apa-apa. Perencanaan memegang peranan penting dalam pelaksanaan program madrasah, ada berbagai macam pendekatan dalam perencanaan. Hasil penelitian Priyanto (2011) menyatakan bahwa pendekatan perencanaan dari bawah ke atas dan dari atas ke bawah. Mekanisme perencanaan dari bawah ke atas biasanya dilakukan karena ingin memenuhi kebutuhan nyata masyarakat terhadap pendidikan. Perencanaan dari bawah ke atas ini dimulai prosesnya dengan mengenali kebutuhan di tingkat masyarakat yang secara 
langsung yang terkait dengan pelaksanaan dan mendapat dampak dari kegiatan pendidikan yang direncanakan.

Dalam membuat perencanaan program harus disesuaikan dengan visi dan misi madrasah. Buchari \& Saleh (2016) menyatakan bahwasanya harus diarahkan untuk menunjang tercapainya tujuan tersebut. Madrasah unggulan harus dirancang sesuai dengan visi-misi dan tujuan kelembagaan, analisis kebutuhan sistem akademik dan kelembagaan, dan memahami konteks geografis dan budaya. Kemudian hasil penelitian Hasanah et.al (2019) Perencanaan pengembangan madrasah untuk menuju madrasah yang unggul yaitu: dimulai dari perbaikan proses belajar mengajar, selanjutnya benahi sistem penerimaan peserta didik baru (input), guru harus profesional dan berkompeten, tersedianya sarana prasarana sebagai pendukung, management berwawasan global dan progresif serta pandangan jauh ke depan, ekstra kurikuler sebagai ajang apresiasi potensi diri anggaran yang cukup untuk memenuhi kebutuhan.

Pada penelitian terdahulu telah banyak membahas tentang pendekatan perencanaan, perencanaan harus disesuaikan dengan visi dan misi madrasah, kemudian perencanaan dimulai dari perbaikan proses belajar mengajar, selanjutnya benahi sistem penerimaan peserta didik baru (input), guru harus profesional dan berkompeten, tersedianya sarana prasarana sebagai pendukung, management berwawasan global dan progresif serta pandangan jauh ke depan, ekstra kurikuler sebagai ajang apresiasi potensi diri anggaran yang cukup untuk memenuhi kebutuhan. Namun dalam penelitian ini memfokuskan pada perencanaan madrasah dalam menyiapkan program seperti tahfiz al-qur`an sebagai daya tarik atau rangsangan madarasah dalam menarik perhatian orang tua siswa untuk menyekolahkan anaknya ke madrasah.

\section{METODE PENELITIAN}

Penelitian ini menggunakan pendekatan kualitatif dengan metode fenomenologi. Metode fenomenologi bertujuan untuk mengambarkan makna dari pengalaman pengelolaan Madrasah Ibtidaiyah Assidiq Giriyoso dalam merencanakan program madrasah. Penelitian ini dilaksanakan di Madrasah Ibtidaiyah Assidiq Giriyoso Kecamatan Jayaloka Kabupaten Musi Rawas. Penelitian dilakukan langsung turun kelapangan dalam masa tertentu, beberapa minggu, beberapa bulan atau lamanya menuntut kecukupan data yang diperoleh. Selama penelitian, peneliti berusaha membuat atau menciptakan hubungan interaksi sosial dan berusaha memahami keadaan yang nyata apa yang terjadi dilapangan

Subyek dalam penelitian ini adalah segenap orang yang dipandang oleh peneliti dapat memberikan data tentang pengelolaan Madrasah Ibtidaiyah dalam meningkatkan mutu lulusan. Subyek penelitian terdiri dari Kepala Sekolah, Dewan Guru, Pihak Yayasan, Siswa, Komite Sekolah, dan Wali Siswa. Teknik Pengumpulan Data meliputi; observasi, wawancara dan dokumentasi. Langkah 
analisis data dalam peneltian ini menggunakan interactive model dari Miles dan Huberman, dimana proses analisis dilakukan bersamaan dengan proses observasi dan wawancara serta dokumentasi langsung dilakukan analisis. Dengan model interactive ini, memungkinkan dilakukan analisis data di lapangan pada saat peneliti sedang melakukan penelitian maupun setelah kembali dari penelitian. Jadi dalam penelitian kualitatif terdapat fleksibelitasi pola atau metode, namun demikian peneliti harus teliti, peka sehingga dalam menggali data dapat menjelaskan fakta atau apa yang terjadi sebenarnya.

Langkah analisis data dengan model ini terdiri atas tahap kegiatan yaitu: pengumpulan data, reduksi data, penyajian data dan penyimpulan data. Pengumpulan data dilakukan dengan dengan tehnik pengamatan, wawancara dan studi dokumentasi. Data yang diperoleh dilapangan dicatat dalam bentuk catatan lapangan yaitu uraian data yang diperoleh. Reduksi merupakan proses memilih data, yang relevan untuk menjawab pertanyaan peneliti. Setelah reduksi, ditentukan komponen yang lebih terfokus untuk di amati dan diwawancarai kembali.

\section{HASIL PENELITIAN}

Perencanaan merupakan langkah awal yang sangat penting dalam menjalanakn lembaga atau organisasi, tanpa perencanaan yang baik, maka sangatlah sulit suatu kegiatan organisasi dapat tercapai dengan baik. Perencanaan peserta didik sangatlah penting dilakukan dengan baik, sebab daya tamping sangatlah penting menjadi perhatian sekolah/madrasah, perencanaan peserta didik sangatlah tergantung juga dengan jumlah guru dan sarana dan prasarana yang tersedia di sekolah. Hasil wawancara dengan Kepala Madrasah Giriyoso, yakni sebagai berikut:

"Dalam merencanakan untuk menerima siswa, sangatlah memperhatikan jumlah guru dan sarana dan prasarana yang tersedia, dan kemudian juga kami melakukan perencanaan untuk promosi kepada wali siswa, dengan menawarkan keunggulan madrasah kami ini”.

Memang dalam merencanakan untuk penerimaan siswa baru, tidak terlepas dari perencanaan promosi sekolah yang baik, apalagi sistem promosi menawarkan keunggulan program sekolah, sehingga wali siswa dapat tertarik langsung untuk menitipkan anaknya bersekolah di Madrasah. Namun jika sekolah tidak merencanakan dengan baik dalam promosi Madrasah, maka Madrasah akan kesulitan dalam mendapatkan siswa untuk bersekolah. Hasil wawancara dengan salah seorang guru Madrasah, yakni sebagai berikut: 
"sebagai guru, kami terlibat langsung dalam merencanakan penerimaman siswa baru melalui promosi program unggul sekolah, sebab dengan cara seperti ini dapat menarik perhatian orang tua untuk menyekolah anaknya ke Madrasah, walaupun Sekolah Dasar Negeri (SDN) sangatlah tidak berjauhan dengan lokasi Madarasah kami, namun kami dapat bersaing dengan baik dalam penerimaan siswa baru".

Untuk mendukung program unggulan madrasah sangatlah diperlukan tenaga pendidik dan kependidikan yang berkompetensi yang tidak hanya mampu mengajar dapat juga dapat membankitkan kreatifitas siswa dalam proses belajar dan mengajar di Madrasah. Perencanaan penerimaan tenaga pendidik dan kependidika hendaknya juga harus disesuaikan dengan visi dan misi Madrasah yang tertuang dalam program madrasah, agar program madrasah dapat berjalan dengan baik. Hasil wawancara dengan Ketua Yayasan, sebagai berikut:

"Saya dalam mengangkat guru dan staf administrasi disesuaikan dengan kebutuhan sekolah, sehingga program sekolah yang akan dijalankan dapat berjalan dengan baik, misalnya sekolah merencanakan program tahfiz qur`an, maka kami juga merencanakan guru yang fasih dan hafal qur`an”.

Untuk mendukung program sekolah tidak dapat terlepas dari dukungan sarana dan prasarana sekolah, agar program yang akan dilaksanakan dapat berjalan dengan baik. Namun jika sarana dan prasaran kurang mendukung, maka program yang telah direncanakan kurang dapat berjalan dengan baik. Perencanaan sarana dan prasarana sangatlah penting dalam pengelolaan kesiswaan, tenaga pendidik dan kependidikan begitu juga dengan keuangan, tanpa perencanaan sarana dan prasaran yang baik, maka seluruh komponen sekolah tidak akan berjalan dengan baik pula. Hasil wawancara dengan salah seorang guru, yakni sebgaai berikut:

"sangatlah penting mempersiapkan atau merencanakan sarana dan prasaran madrasah dengan baik untuk mendukung terlaksananya program sekolah yang telah dibuat".

Disamping itu juga dalam memajukan madrasah tidak dapat terlepas dari perencanaan kurikulum yang baik, kurikulum direncanakan dengan baik dan dikemas dengan baik oleh guru agar dalam penyampain materi dapat terlaksana dengan baik dan juga dalam merencanakan kurikulum tidak dapat terlepas juga dengan program sekolah yang telah ditetapkan. Maka dari itu peran gruu sangatlah strategis dalam merencanakan kurikulum dalam bentuk rencana pelaksanaan pembelajaran (RPP) dengan baik. Hasil wawancara dengan kepala sekolah, yakni sebagai berikut: 
"memang saya selaku kepala sekolah selalu menekankan kepada guru dalam merencanakan kurikulum dalam bentuk rencana pelaksanaan pembelajaran dapat direncanakan dengan baik, agar program dan tujuan sekolah dapat terlaksana dengan baik pula"

Disamping kurikulum, hal yang tidak kala pentingnya, yaitu perencanaan keuangan, keuangan yang ada yang terdiri dari berbagai sumber hendaknya dapat dialokasikan dan direnacanakan dengan baik, agar dalam operasionalnya dapat tercukupi, jika tidak demikian, maka dalam pelaksanaan akan mengalami hambatan sehingga program sekolah kurang dapat berjalan dengan baik, maka dari itu sangatlah penting untuk merencanakan keuangan yang baik. Hasil wawancara dengan ketua yayasan, yakni sebagai berikut:

"Saya selaku ketua yayasan untuk menekankan kepada Madrasah untuk merencanakan keuangan dengan baik terutama sumber keuangan, saya memerintahkan kepada kepala sekolah untuk membuat proposal dan diajukan kepada angota dewan sebagai wakil rakyat untuk mendukung kegiatan pendidikan dalam bentuk dana reses dewan, disamping itu juga memintak bantuan warga sekitar yang memiliki kemampuan ekonomi yang baik untuk mendukung program madrasah".

Memang sangatlah benar perencanaan keuangan sangatlah penting dalam mendukung program sekolah, sebab tanggungjawab pendidikan bukan hanya sekdar di madrasah namun, orang tua dan masyarakat dapat dilibatkan dalam kemajuan sekolah, sehingga untuk mendukung program sekolah sangatal diperlukan perencanaan untuk melibatkan masyarakat dalam kemajuan sekolah, sehingga masyarakat dapat berperan serta dalam kemajuan sekolah, namun hal ini sangatlah diperlukan perencanaan yang baik dan dituangan dalam program, sehingga keterlibatan masyarakt menjadi optimal dalam mendukung kemajuan sekolah. Hasil wawancara dengan kepala sekolah, yakni sebagai berikut:

"masyarakat sering kami libatkan dalam pelaksaaan program sekolah, dimana kami sering mealakukan kerjasama dalam membangun madrasah, baik secara materil dan maupun moril, hal ini kami lakukan sebagai upaya untuk memajukan madrasah"

Memang sangatlah penting merencanakan seluruh komponen sekolah dalam mensukseskan program unggulan madarasah, mulai dari perencanaan kesiswaan, kurikulum, pendididik dan tenaga pendidikan, keuangan, serta hubungan masyarakat, dalam kegiatan perencanaan dapat melibatkan masyarakat sebagai elemen penting untuk mendukung kemajuan madrasah. Kemudian peran wakil rakyat dapat dijadikan relasi atau hubungan baik dalam memajukan Madrasah. 


\section{PEMBAHASAN}

Membuat program unggulan dalam hal ini program rumah tahfiz al`qur`an tidak dapat terlepas dari kegiatan perencanaan, dimulai dari perencanaan kesiswaan sebagai peserta didik, tenaga pendidik dan kependidikan perlu dipersiapkan dengan baik, sarana dan prasarana, kurikulum, keuangan dan hubungan masyarakat. Madrasah ibtidiayah Giriyoso telah merencanakan program tahfiz qur`an dengan menyiapkan sarana pendukung seperti pondok tahfiz yang berada di depan kelas, tenaga pendidik dan kependidikan yang fasih dan hafal alqur`an, kurikulum yang tercantum dalam rencana pelaksanaan pembelajaran, kemudian menjalin hubungan baik dengan masyarakat terutama dalam mendukung program tahfiz al-qur`an.

Mewujudkan program madrasah yang unggul tidak dapat terlepas dari perencanaan yang unggul juga. Hasil penelitian Sabirin (2012) menyatakan bahwasanya inti dari perencanaan adalah bagaimana proses pelaksanaannya. Karena rencana apapun yang dibuat kalau tidak dilaksanakan maka semua rencana tersebut tidak mempunyai arti apa-apa. Perencanaan memegang peranan penting dalam pelaksanaan program madrasah, ada berbagai macam pendekatan dalam perencanaan. Hasil penelitian Priyanto (2011) menyatakan bahwa pendekatan perencanaan dari bawah ke atas dan dari atas ke bawah. Mekanisme perencanaan dari bawah ke atas biasanya dilakukan karena ingin memenuhi kebutuhan nyata masyarakat terhadap pendidikan. Perencanaan dari bawah ke atas ini dimulai prosesnya dengan mengenali kebutuhan di tingkat masyarakat yang secara langsung yang terkait dengan pelaksanaan dan mendapat dampak dari kegiatan pendidikan yang direncanakan.

Dalam membuat perencanaan program harus disesuaikan dengan visi dan misi madrasah. Buchari \& Saleh (2016) menyatakan bahwasanya harus diarahkan untuk menunjang tercapainya tujuan tersebut. Madrasah unggulan harus dirancang sesuai dengan visi-misi dan tujuan kelembagaan, analisis kebutuhan sistem akademik dan kelembagaan, dan memahami konteks geografis dan budaya. Kemudian hasil penelitian Hasanah et.al (2019) Perencanaan pengembangan madrasah untuk menuju madrasah yang unggul yaitu: dimulai dari perbaikan proses belajar mengajar, selanjutnya benahi sistem penerimaan peserta didik baru (input), guru harus profesional dan berkompeten, tersedianya sarana prasarana sebagai pendukung, management berwawasan global dan progresif serta pandangan jauh ke depan, ekstra kurikuler sebagai ajang apresiasi potensi diri anggaran yang cukup untuk memenuhi kebutuhan.

Kemudian peran kepemimpinan yang tegas, cerdas dan tim yang solid menjadi bagian penting dalam pengelolaan madrasah yang unggul. Hasil penelitian Katni \& Rois (2015) seluruh elemen pengelola di madrasah menjadi suatu tim yang solid, saling berinteraksi, berkomunikasi dan menjalin hubungan yang sangat erat karena mereka dipimpin oleh kepala sekolah yang tegas, terbuka, apa adanya serta jujur. Hasil penelitian Masudah (2016) organisasi 
manajemen madrasah memerlukan pimpinan/manajer yang mengerti benar konsep dasar manajemen strategi dan mutu madrasah ibtidaiyah agar manajer tersebut memiliki visi yang bijaksana dan mampu mengilhami staf/pekerja dan semua komunitas organisasi madrasah ibtidaiyah.

Keterpenuhan standar pendidikan madrasah juga merupakan komponen yang tidak dapat dipisahkan dalam menciptakan madrasah yang unggul. Hasil penelitian Eriyanto (2019) madrasah hendaknya lebih memberdayakan setiap komponen penting madrasah dalam hal standar isi, standar proses, standar kompetensi lulusan, standar penilaian dan standar pengelolaan dalam rangka pencapaian tujuan, visi dan misi madrasah.

Lembaga pendidikan madrasah harus optimis, produk madrasah dapat bersaing dengan sekolah umum lainnya, untuk mampu bersaing dengan sekolah umum lainnya setidaknya ada beberapa langkah-langkah strategis yang harus dilaksanakan, yakni perencanaan, pengorganisasian, kepemimpinan, pengarahan, penggerakan, pengkomunikasian, pengkoordinasian, pengendalian, monitoring evaluasi, penganggaran, dan ruanglingkup manajemen pendidikan (Suprapti, 2014).

\section{SIMPULAN}

Madrasah ibtidiayah Giriyoso telah merencanakan program tahfiz qur'an dengan menyiapkan sarana pendukung seperti pondok tahfiz yang berada di depan kelas, tenaga pendidik dan kependidikan yang fasih dan hafal alqur’an, kurikulum yang tercantum dalam rencana pelaksanaan pembelajaran, kemudian menjalin hubungan baik dengan masyarakat terutama dalam mendukung program tahfiz al-qur`an.

\section{DAFTAR PUSTAKA}

Buchari, A., \& Saleh, E.,M. (2016). Merancang Pengembangan Madrasah Unggul. Journal of Islamic Education Policy, 1(2), 95-112

Eriyanto. (2019). Pengelolaan Madrasah yang Efektif: Menjawab Tantangan Pendidikan Islam di Era Industri 4.0, Jurnal Pendidikan Islam Indonesia, 4(1), 74-88

Hasanah, W., Nurhayati, Zulham, T., Rahmat, H. (2019). Perencanaan Pengembangan Madrasah di MAS Teladan Ujung Kubu Kecamatan Tanjung Tiram Kabupaten Batu Bara, Sabilarrsyad, 4(1), 33-43

Katni, \& Rois, A.,K. (2015). Pengelolaan Madrasah dalam Perspektif Manajemen Mutu Terpadu. Muaddib, 5(2), 111-134

Madarik, M. (2016). Manajemen Madrasah dalam Perspektif Islam. CENDEKIA: Jurnal Studi Keislaman, 2(1), 123-147

Masudah, (2016). Konsep Dasar Manajemen Strategi dan Mutu Madrasah Ibtidaiyah, Jurnal Didaktika Islamika, 7(1), 131-155 
Peraturan Pemerintah Nomor 19 Tahun 2005 Tentang Standar Nasional Pendidikan

Priyanto, D. (2011). Pengembangan Perencanaan Pendidikan Islam, Insanian, 16(3), 295-307

Sabirin. (2012). Perencanaan Kepala Sekolah tentang Pembelajaran, Jurnal Tabularasa PPS Unimed, 9(1), 111-128

Suprapti. (2014). Analisis Kritis Manajemen Madrasah Di Era Otonomi Daerah, Religi;Jurnal Studi Islam, 5(1), 102-123 